\title{
Displacement of a composite restoration fragment into the gingiva: an unusual complication of surgical removal of teeth
}

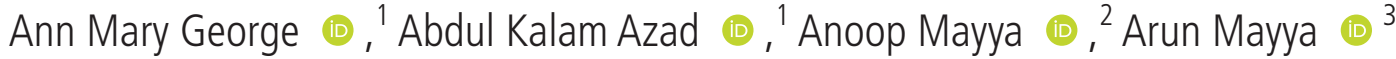

\begin{abstract}
${ }^{1}$ Oral and Maxillofacial Surgery, Melaka Manipal Medical College, Melaka, Malaysia ${ }^{2}$ Prosthodontics, Melaka Manipal Medical College, Melaka, Malaysia

${ }^{3}$ Conservative Dentistry and Endodontics, Srinivas Institute of Dental Sciences, Mangalore, India
\end{abstract}

\section{Correspondence to Dr Anoop Mayya;} anoopmayya@gmail.com

Accepted 6 April 2021
Check for updates

(C) BMJ Publishing Group Limited 2021. No commercial re-use. See rights and permissions. Published by BMJ.

To cite: George AM,
Azad AK, Mayya A, et al. BMJ
Case Rep 2021;14:e240294.
doi:10.1136/bcr-2020-
240294

\section{DESCRIPTION}

In the maxillofacial region, foreign bodies occur due to trauma or therapeutic interventions. ${ }^{1}$ One of the most commonly reported foreign bodies in the jaw bones are filling materials. ${ }^{2}$ Ghafoor et al described a rare case in which a wide area of bone loss with loss of two teeth was related to an intra-osseous foreign body reaction due to amalgam displacement in the extraction socket. ${ }^{3}$ Another clinical case by Fredrik et al illustrated calcium hydroxide paste displacement into the mandible and the advantages of retrieving such displaced material before symptoms worsen. ${ }^{4}$ Multiple imaging techniques can be used to localise the foreign bodies which include plain radiographs, CT, MRI or ultrasound. ${ }^{5}$ This case clearly demonstrates an iatrogenic cause for discomfort and irritation of the mandible due to a displaced composite restoration fragment requiring surgical referral and treatment, which was potentially avoidable.

A 25-year-old male patient presented with a complaint of discomfort in the left mandible since last 6 months. On inspection, the area of discomfort was localised in the region of teeth \#36 and \#37. There was mild erythema and swelling in the region. There was no facial swelling, cervical lymphadenopathy or trismus on physical examination. Intra-oral examination did not reveal tenderness, pus discharge, bleeding or any other secondary symptoms. A composite restoration was noticed on tooth \#37. The patient had a history of surgical removal of tooth \#38 6 months prior. Panoramic radiograph did not show any significant findings. The patient was advised to maintain good oral hygiene and gargle with saltwater three times per day for 2 weeks. A review was scheduled after 2 weeks during which the patient did not report any change in the symptoms. A Cone Beam Computed Tomography (CBCT) was advised, which revealed a small radio-opaque area in the gingival soft tissue overlying in the alveolus lateral to teeth \#36 and \#37 (figure 1).

The patient was prepared, and surgical retrieval of the foreign body was performed after taking a thorough medical history. An inferior alveolar nerve block was administered using 2\% lidocaine with 1:100000 epinephrine. A modified wards incision was placed, and the flap was carefully reflected, not to displace the foreign body. A white coloured material was observed after careful exploration in between teeth \#36 and \#37 (figure 2). The material was seen to be embedded between the
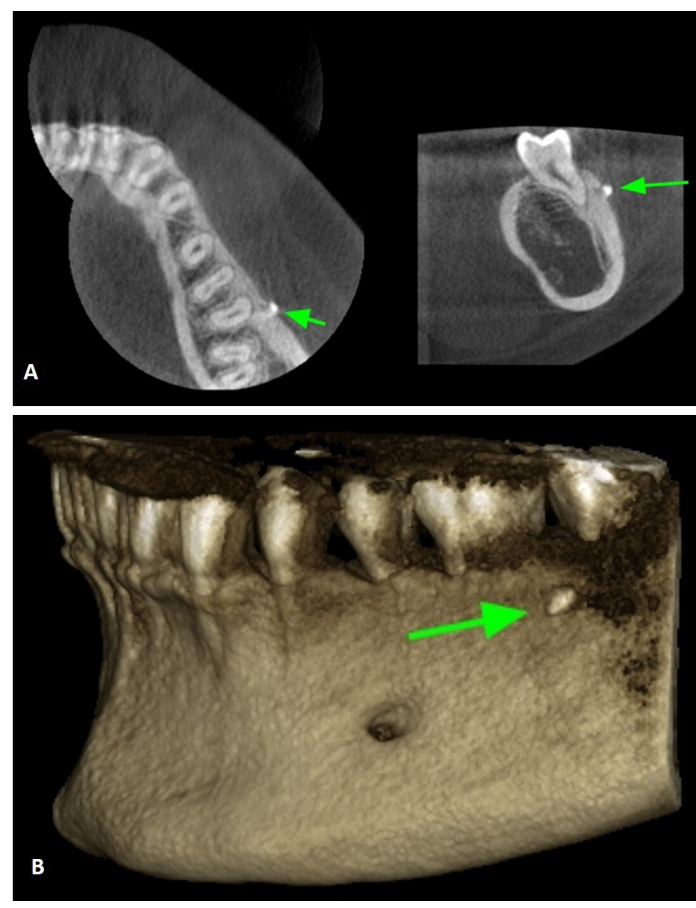

Figure 1 (A) Cone Beam Computed Tomography (CBCT) of the patient, green arrow pointing to the foreign body between teeth \#36 and \#37. (B) Three-dimensional (3D) $\mathrm{CT}$ of the patient, green arrow pointing to the foreign body between teeth \#36 and \#37 (scale 1.43) Planmeca 3Ds CBCT unit (Helsinki, Finland); $200 \mu \mathrm{m}$ voxel, 90 kvP, $12 \mathrm{~mA}, 12.35 \mathrm{~s}$ exposure.

periosteal layer and the bone. The foreign body was then removed cautiously, and the site was irrigated well with saline. The flap was secured with simple interrupted sutures using (3-0) silk. On careful

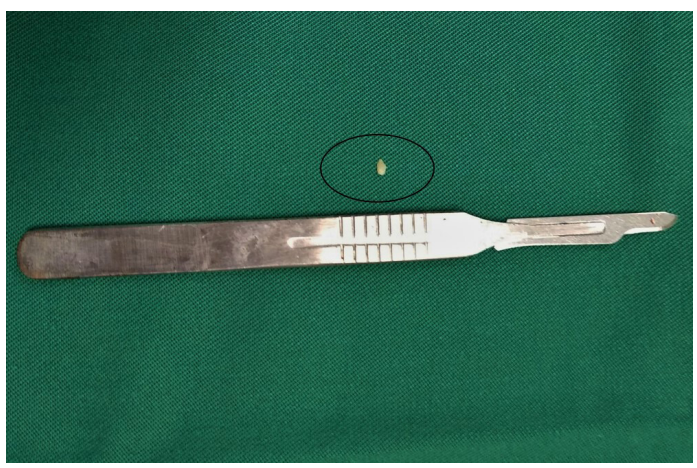

Figure 2 The retrieved composite particle from the mandible is encircled. 
inspection of the adjacent area, it was found that a small piece of the composite restoration had chipped off from the distal most aspect of the tooth \#37 and had displaced into the gingival soft tissue overlying the mandible, which in turn caused the irritation. The patient when reviewed 2 weeks postoperatively was asymptomatic.

\section{Learning points}

- Dentists should be mindful of restorations on teeth adjacent to surgical site.

- In case of any doubt of dislodged fragments of restoration, attempts should be made to recover them from the tissues.

- Most displaced foreign bodies in mandible are found only during imaging or when patients complain of symptoms.

Contributors AMG contributed to patient treatment, conception and design. AKA contributed to drafting the work and revising it critically for important intellectual content. AnM contributed to defining intelectual content, design, literature review and manuscript editing. ArM contributed to literature review and manuscript editing.
Funding The authors have not declared a specific grant for this research from any funding agency in the public, commercial or not-for-profit sectors.

Competing interests None declared.

Patient consent for publication Obtained.

Provenance and peer review Not commissioned; externally peer reviewed.

\section{ORCID iDs}

Ann Mary George http://orcid.org/0000-0002-5761-4818

Abdul Kalam Azad http://orcid.org/0000-0002-9565-4140

Anoop Mayya http://orcid.org/0000-0001-6583-4311

Arun Mayya http://orcid.org/0000-0002-7230-3479

\section{REFERENCES}

1 Omezli MM, Torul D, Sivrikaya EC. The prevalence of foreign bodies in jaw bones on panoramic radiography. Indian J Dent 2015;6:185-9.

2 Eggers G, Mukhamadiev D, Hassfeld S. Detection of foreign bodies of the head with digital volume tomography. Dentomaxillofac Radiol 2005;34:74-9.

3 Ghafoor M, Halsnad M, Grew N. Restoration fragments. Br Dent J 2011;210:558-9.

4 Ahlgren FKEK, Johannessen AC, Hellem S. Displaced calcium hydroxide paste causing inferior alveolar nerve paraesthesia: report of a case. Oral Surg Oral Med Oral Pathol Oral Radiol Endod 2003;96:734-7

5 Javadrashid R, Fouladi DF, Golamian M, et al. Visibility of different foreign bodies in the maxillofacial region using plain radiography, CT, MRI and ultrasonography: an in vitro study. Dentomaxillofac Radiol 2015;44:20140229.

Copyright 2021 BMJ Publishing Group. All rights reserved. For permission to reuse any of this content visit https://www.bmj.com/company/products-services/rights-and-licensing/permissions/

BMJ Case Report Fellows may re-use this article for personal use and teaching without any further permission.

Become a Fellow of BMJ Case Reports today and you can:

- Submit as many cases as you like

- Enjoy fast sympathetic peer review and rapid publication of accepted articles

- Access all the published articles

Re-use any of the published material for personal use and teaching without further permission

\section{Customer Service}

If you have any further queries about your subscription, please contact our customer services team on +44 (0) 2071111105 or via email at support@bmj.com.

Visit casereports.bmj.com for more articles like this and to become a Fellow 